\title{
KONSTRUKSI EKOLOGIS ARSITEKTUR MESJID ZIARAH NUSANTARA Studi kasus: Mesjid Ziarah Ampel Surabaya
}

\author{
Mappaturi \\ UIN Maulana Malik Ibrahim, Fakultas Saintek \\ mappa putri@yahoo.co.id
}

\begin{abstract}
ABSTRAK
Ekologi arsitektur adalah keselarasan antara bangunan dengan alam sekitarnya, mulai dari Atmosfer, biosfer, Lithosfer serta komunitas. Unsur-unsur ini berjalan harmonis menghasilkan kenyaman, kemanan, keindahan serta ketertarikan. Melalui jelajah kasus Masjid Ampel, riset ini berupaya mengungkapkan konstruksi ekologis arsitektural masjid ziarah sebagai alternatif keberlanjutan arsitektur yang berkarakter Nusantara. Langkah awalnya adalah melakukan jelajah atas masjid tersebut dengan menggunakan kajian visual culture sebagai alat bacanya. Langkah berikutnya adalah melakukan kajian interpretif atas identitas masjid dan konsep sosio-ekologi arsitekturalnya. Penelitian ini menghasilkan rumusan arsitektur ekologis yang berpijak pada kenusantaraan dan kekinian arsitektural. Rumusan ini bisa dijadikan sebagai strategi pengembangan dan pembaharuan arsitektur masjid yang menusantara, mengkini, sekaligus berwawasan eko arsitektur.
\end{abstract}

Kata Kunci: ekologis, nusantara, ramah lingkungan, hemat energi

\section{Pendahuluan}

Dalam pergumulannya dengan kebudayaan lokal Nusantara, Muslim Indonesia memiliki karakter yang khas. Karakter itu adalah menyatu dengan kebudayaan masyarakat Nusantara tanpa bermaksud menundukkan dan menggantikannya menjadi Islam versi Arab. Jika kita merunut pada sejarah masa lalu, peradaban Islam Nusantara bisa tampil dengan karakter lokal yang kuat sehingga bisa memberi pengaruh kepada wilayah-wilayah peradaban di sekitarnya.

Arsitektur Muslim Nusantara menunjukkan penyadaran bahwa arsitektur mengada (eksis) secara bersama dengan masyarakat manusianya dan dengan lingkungan alam dan binaan di sekitarnya (Pangarsa, 2010). Arsitektur ini menunjukkan sistem dan struktur yang sangat kompleks, satu kesatuan jalinan kehidupan masyarakat manusia dan lingkungan alam. Konsep kemasyarakatan Nusantara menunjukkan hubungan antar dan antara masyarakat manusia dan lingkungan alam yang serasi. Hubungan tersebut harus selaras (tak saling bertolakbelakang), manusia tak menindas hak sesama dan hak lingkungan alam ruang huniannya, ramah, santun, dan berada pada titik perimbangan.

Ironisnya, peradaban muslim Indonesia yang sebenarnya punya potensi besar untuk berkembang dan memberi pengaruh kepada dunia pada saat ini relatif tidak dikenal dalam peta peradaban dunia. Dengan kata lain, muslim Indonesia mengalami keterpinggiran dalam peradaban dunia. Hingga saat ini, pusat peradaban dunia -Eropa dan Amerika- hanya mengenal peradaban Islam, termasuk wujud fisik arsitektur masjidnya, yang berwajah Timur Tengah, Persia, dan Turki.

Di Nusantara, dalam perancangan arsitektur masjid, tampak ada upaya pelestarian kenusantaraan meskipun hanya dianut oleh segelintir arsitek. Upaya ini mampu memberikan kontribusi bagi penciptaan karakter peradaban lokal muslim 
yang menusantara demi pembentukan kebaruan identitas yang memuat nilai-nilai universal Islam dan lokal Nusantara. Upaya pelestarian karakter Nusantara ini bisa saja sebatas penyelesaian rupa atau wujud fisik arsitektural. Tetapi bisa dengan cara yang lebih baik, dengan menemukan inti dasar karakternya dan kemudian menumbuhkembangkannya dengan wujud baru sesuai dengan konteks ruang dan zamannya (Pangarsa, 2006). Inti dasar ini adalah kemanusiaan. Fitrah setiap manusia adalah berkehidupan serba damai, tentram, selaras dan serasi baik dengan masyarakat manusia maupun lingkungan alam sekitarnya.

Menurut Wahid (2011), masjid seharusnya memiliki fungsi membentuk jiwa keislaman yang mampu berdialog dengan budaya setempat dan juga mampu menghadapi dinamika perubahan zaman. Fungsi ini mengejawantah dalam wujud visual arsitekturnya. Arsitektur masjid di ranah Nusantara menunjukkan satu kesatuan sistem dan struktur jalinan kehidupan masyarakat manusia beserta lingkungannya. Masjid Ziarah Wali di Jawa Timur yang dijadikan objek penelitian, memiliki karakter ekologis dan keberlanjutan dalam gerak waktu yang terus maju. Karakter ini lahir dari hasil kontestasi dan integrasi pengaruh antara unsur universal Islam, lokalitas Nusantara, kebersamaan, dan keadilmakmuran. Pengembangan karakter sosio-ekologi dalam konteks arsitektur ini menjadikan pesantren berpotensi untuk memberi pengaruh kepada wilayah-wilayah peradaban di sekitarnya.

Penelitian ini berusaha untuk menggali konstruksi ekologi arsitektural dari salah satu Masjid Ziarah Wali di Jawa Timur, yaitu Masjid Sunan Ampel Surabaya. Karakter ekologi memberikan kotribusi dan pengaruh bagi pengembangan arsitektur muslim setempat dan bagi peta peradaban muslim Nusantara. Langkah utama yang perlu dilakukan adalah upaya menemukan kembali dan mengembangkan karakter sosio-ekologinya, dengan melakukan pembacaan kritis atas arsitektur masjid. Karakter sosio-ekologi arsitektural adalah ungkapan pemikiran yang berupa filosofi, konsep, dan wujud visual, yang menekankan arsitektur untuk bersifat memanusiakan manusia dan menyelaraskan diri dengan lingkungannya, serta menekankan karakter identitas beserta kontribusinya dalam berkehidupan sosial. Karakter ini diperlukan untuk mengembangkan/mempertahankan eksistensi arsitektur.

Masjid Ampel di Surabaya dibangun oleh Sunan Ampel pada tahun $1450 \mathrm{M}$. Penampilan masjid sekarang adalah hasil beberapa kali perluasan dan renovasi, mulai era kolonial hingga akhir abad XX. Menurut Santoso (1999), bangunan masjid lama mengacu pada tipe Demakan, berdenah bujursangkar, di dalamnya terdapat empat tiang (sakaguru) dari kayu jati, yang menyangga atap piramid (tajug) bersusun dua. Di dalam bangunan induk ini juga terdapat menara dengan puncak yang beratap kerucut. Di sekeliling bangunan induk ini terdapat serambi. Langgam Demakan pada masjid lama ini, juga dipadukan dengan langgam Indische Empire, yang terwujudkan pada unsur dinding tebal, dan pintu dengan unsur lengkung di bagian atasnya. Langgam ini sangat populer pada masa kolonial, saat bangunan direnovasi dan diperluas. 


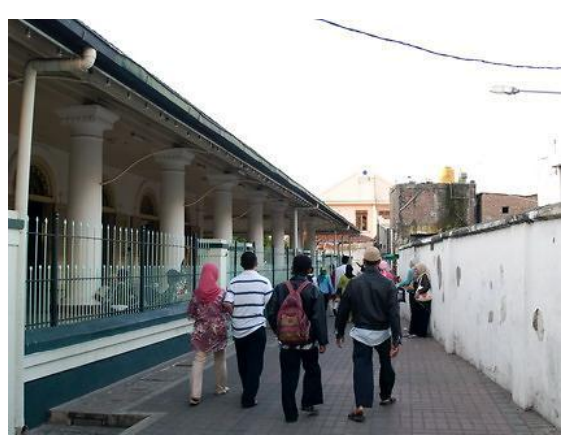

Gambar 1. Bangunan masjid Ampel lama, memiliki kombinasi langgam Jawa dengan Indis Empire, seperti yang ditunjukkan oleh kolom besar dan pintu yang lebar

Bangunan perluasan masjid terletak di sebelah utara, dan masjid baru terletak di sebelah barat laut masjid lama. Renovasi terbesar dan menyeluruh dilaksanakan pada tahun 1990-an, dengan melakukan penataan seluruh kompleks masjid, dan penambahan beberapa bangunan. Pada bagian perluasan masjid, terhadirkan perpaduan antara style setempat, seperti atap piramid (tajug), dengan unsur pendatang bergaya Modern dan Pan Islamic, berupa komposisi geometri dan arabesk. Atap masjid baru menunjukkan perpaduan antara style setempat dan style pendatang, seperti atap piramid (tajug) yang berupa rusuk-rusuk pada bagian puncaknya, dan kubah yang berada di dalamnya (Santoso, 1999).

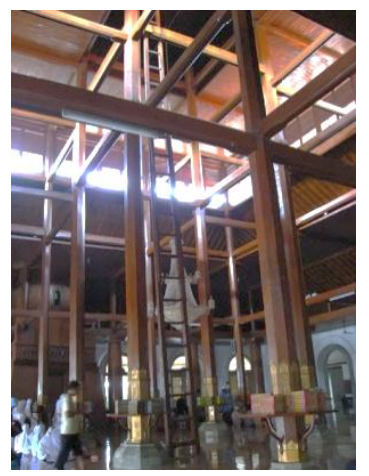

Gambar 2. Ruang dalam masjid Ampel lama yang didominasi unsur struktur kayu

Berkaitan dengan hal di atas, permasalahan dalam penelitian ini adalah:

a. Bagaimana karakter ekologis arsitektural pada bentuk dan ruang arsitektur Masjid Ziarah Ampel di Surabaya, yang nantinya dapat dijadikan sebagai ancangan dalam upaya membangun pedoman dan strategi rekontekstualisasi dan keberlanjutan arsitektur Masjid Nusantara yang lebih baik dan kontekstual?

b. Bagaimana merumuskan sebuah ancangan atau pedoman strategi merancang arsitektur Masjid Nusantara, yang bisa memandu kegiatan membangun arsitektur yang berkarakter ekologis?

\section{Bahan dan Metode}

\subsubsection{Kajian Pustaka}

Dalam pembahasan arsitektur masjid di Nusantara, masjid bercorak Nusantara memiliki karakter vernakuler, dengan ciri-ciri, "bahasa", budaya, kondisi lingkungan termasuk iklim setempat. Sedangkan yang lainnya (seperti unsur kubah dan menara) adalah corak bukan Nusantara yang dibangun di Indonesia. Menurutnya, aspek dalam arsitektur yang tersurat dan tersirat jelas dan langsung dalam al-Qur'an (keislaman) hanyalah orientasi ke arah kiblat, ditandai dengan mihrab. Tentang keindahan, kemegahan, kebersihan sebetulnya ada dalam ayat-ayat suci al-Qur'an maupun Hadits namun tidak langsung terkait dengan arsitektur masjid. Bahkan yang berlebihan 
misalnya kemewahan adalah hal yang sebetulnya kurang sesuai dengan Islam (Sumalyo, 2000).

Arsitektur ekologis merupakan pembangunan berwawasan lingkungan, dimana memanfaatkan potensi alam semaksimal mungkin. Kualitas arsitektur biasanya sulit diukur. Kualitas arsitektur biasanya hanya memperhatikan bentuk bangunan dan konstruksinya, tetapi mengabaikan yang dirasakan si pengguna dan kualitas hidupnya. 4 komponen arsitektur yang diukur dalam penelitian ini adalah:

\section{Holistik}

Istilah eko-arsitektur adalah istilah holistik yang sangat luas dan mengandung semua bidang. Eko-arsitektur tidak menentukan apa yang seharusnya terjadi dalam arsitektur karena tidak ada sifat khas yang mengikat sebagai standar atau ukuran baku. Namun, eko-arsitektur mencakup keselarasan antara manusia dan lingkungan alamnya. Eko-arsitektur mengandung juga dimensi yang lain seperti waktu, lingkungan alam, sosio kultural, ruang, serta teknik bangunan. Hal ini menunjukkan bahwa eko-arsitektur bersifat lebih kompleks, padat, vital dibandingkan dengan arsitektur pada umumnya.

\section{Hemat Energi.}

Manusia memerlukan energi, baik untuk menyediakan makanan, untuk membakar batu bara, dan untuk memproduksi peralatan dalam bentuk apapun sehingga selalu membebani lingkungan alam. Api yang dapat memberikan kehangatan dan menerangi kegelapan tetapi yang juga mengandung kekuatan merusak yang menakutkan, dapat melambangkan energi dan bahan bakarnya. Bahan bakar dapat digolongkan menjadi 2 kategori yaitu yang dapat diperbaharui dan yang tidak dapat diperbaharui. Walaupun kita telah mengetahui perbedaan diantara keduanya, manusia tetap cenderung memanfaatkan energi yang tidak dapat diperbaharui (batu bara, minyak, dan gas bumi) karena dianggap penggunaannya lebih mudah. Penggunaan energi untuk seluruh dunia diperkirakan $3 \times 1014$ MW per tahun, yang berarti bahwa bahaya bagi manusia bukan hanya terletak pada kekurangan energi tetapi juga pada kebanyakan energi yang dibakar dan mengakibatkan kelebihan karbondioksida di atsmosfer yang mempercepat efek rumah kaca dan pemanasan global.

\section{Material Ramah Lingkungan.}

Prinsip-prinsip ekologis dalam penggunaan bahan bangunan adalah: (1). menggunakan bahan baku, energi, dan air seminimal mungkin. Semakin kecil kebutuhan energi pada produksi dan transportasi, semakin kecil pula limbah yang dihasilkan. Bahan-bahan yang tidak seharusnya digunakan sebaiknya diabaikan. (2). Bahan bangunan diproduksi dan dipakai sedemikian rupa sehingga dapat dikembalikan kedalam rantai bahan. (3). Menggunakan bahan bangunan harus menghindari penggunaan bahan yang berbahaya. (4). Bahan yang dipakai harus kuat dan tahan lama. (5). Bahan bangunan atau bagian bangunan harus mudah diperbaiki dan diganti.

\section{Peka Terhadap Iklim}

Bangunan sebaiknya dibuat secara terbuka dengan jarak yang cukup diantara bangunan tersebut agar gerak udara terjamin. Orientasi bangunan ditepatkan diantara lintasan matahari dan angin sebagai kompromi antara letak gedung berarah dari timur ke barat, dan yang terletak tegak lurus terhadap arah angin. Gedung sebaiknya berbentuk persegi panjang yang menguntungkan penerapan. ventilasi silang. 


\section{Hasil Dan Pembahasan}

Konstruksi ekologis mesjid Sunan Ampel saat ini dipersempit dengan tinjauan pada 4 bahasan yaitu holistik, hemat energi, material ramah lingkungan dan peka terhadap iklim.

\section{Holistik}

Tinjauan holistik pada mesjid Sunan Ampel yang paling mudah terbaca adalah adanya kumpulan pepohonan di dekat mesjid. Kumpulan pepohonan ini memberikan banyak manfaat bagi mesjid, baik berupa produksi oksigen pada pagi hingga sore hari, kesejukan karena berkurangnya radiasi matahari, pergerakan angin karena adanya beda daerah terbayang dan tidak dan banyak hal lain.

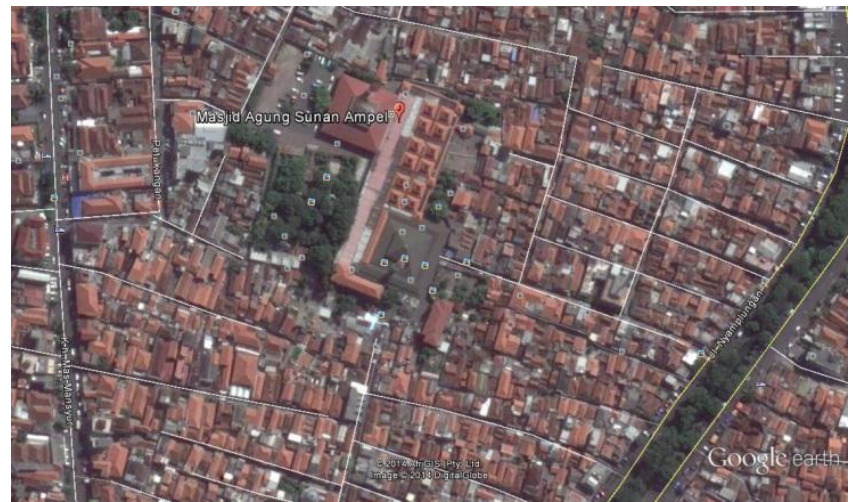

Gambar 3. Tampak Udara Kawasan Mesjid Ziarah Ampel

Bila diamati terlihat jelas dalam radius beberapa puluh bahkan ratusan meter, hanya daerah mesjid Ampellah yang memiliki pohon. Pohon ini memberikan banyak manfaat lainnya selain yang disebutkan di atas. Manfaat lainnya adalah menyaring suara yang berlebih, juga mengurangi debu, memberikan daerah resapan air hujan. Hal inilah yang mungkin juga berpengaruh pada ketersediaan air yang ada terus di daerah ampel. Pepohonan yang banyak menunjukkan keinginan untuk tetap selaras dari pembangunan mesjid dengan lingkungan sekitarnya. Hanya saja yang disayangkan sekarang karena pembangunan perluasan mesjid saat ini sudah tidak memperhatikan keselarasan dengan alam lagi.

Mesjid Ampel dibangun dengan konsep Jawa pada jaman Majapahit dengan atap joglo. Rumah Joglo umumnya terbuat dari kayu Jati. Sebutan Joglo mengarah pada bentuk atap yang menganalogikan sebuah gunung. Bentuk gunung bertujuan untuk mengambil filosofi yang terkandung dan dinamakan Tajug. untuk rumah hunian atau sebagai tempat tinggal, atapnya terdiri dari 2 tajug yang disebut atap Joglo/Juglo / Tajug Loro. Di mesjid ampel disusun dari 3 susun, yang bertujuan untuk membedakan dan menaikkan fungsinya yang lebih tinggi dari rumah tinggal yaitu sebagai tempat peribadatan, pusat kegiatan keisalaman dan pusat untuk titik kumpul penyebaran dakwah Islam. Dalam kehidupan orang Jawa, gunung merupakan sesuatu yang tinggi dan disakralkan. Gunung banyak dituangkan kedalam berbagai simbol, khususnya untuk simbol-simbol yang berkenaan dengan sesuatu yang magis atau mistis. Hal ini karena adanya pengaruh kuat keyakinan bahwa gunung atau tempat yang tinggi adalah tempat yang dianggap suci dan tempat tinggal para Dewa. Ini yang kemudian mungkin diambil oleh sunan ampel untuk mengarahkan kemistisan tersebut hanya pada Allah. Bahwa Allah adalah zat Gaib yang wajib dipercaya.

Pengaruh kepercayaan animisme, Hindu dan Budha masih sangat kental mempengaruhi bentuk dan tata ruang rumah Joglo tersebut contohnya: Dalam rumah 
adat Joglo, umumnya sebelum memasuki ruang induk kita akan melewati sebuah pintu yang memiliki hiasan sulur gelung atau makara. Hiasan ini ditujukan untuk tolak balak, menolak maksud - maksud jahat dari luar hal ini masih dipengaruhi oleh kepercayaan animisme. Kamar tengah merupakan kamar sakral. Dalam kamar ini pemiliki rumah biasanya menyediakan tempat tisur atau katil yang dilengkapi dengan bantal guling, cermin dan sisir dari tanduk. Umumnya juga dilengkapi dengan lampu yang menyala siang dan malam yang berfungsi sebagai pelita, serta ukiran yang memiliki makna sebagai pendidikan rohani, hal ini masih dalam pengaruh ajaran Hindu dan Budha.

Rumah Joglo juga menyiratkan kepercayaan kejawen masyarakat Jawa yang berdasarkan sinkretisme. Keharmonisan hubungan antara manusia dan sesamanya ("kawulo" dan "gusti"), serta hubungan antara manusia dengan lingkungan alam di sekitarnya ("microcosmos" dan "macrocosmos"), tecermin pada tata bangunan yang menyusun rumah joglo. Baik itu pada pondasi, jumlah saka guru (tiang utama), bebatur (tanah yang diratakan dan lebih tinggi dari tanah disekelilingnya), dan beragam ornamen penyusun rumah joglo. Arsitektur rumah Joglo menyiratkan pesanpesan kehidupan manusia terhadap kebutuhan "papan". Bahwa rumah bukankah sekadar tempat berteduh, tapi ia juga merupakan "perluasan" dari diri manusia itu sendiri. Berbaur harmoni dengan alam di sekitarnya. Rumah Joglo pada umumnya sama pada bentuk global dan tata ruangnya. Hal-hal ini yang diambil dan digabungkan dengan Islam.

Bila melihat ke interior mesjid, setelah masuk ke interior bangunan, ada banyak hal yang sangat menarik dari interior mesjid bila dikaitkan dengan bahasan holistic. Kolom kolom yang sangat panjang yang menunjukkan bahwa tidak ada sesuatupun yang tidak mungkin di dunia ini bila Allah berkehendak. Maka janganlah menyerah untuk meminta dan berjuang di jalan Allah.

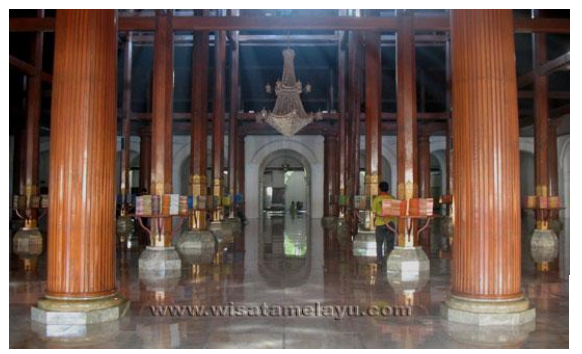

Gambar 4. desain interior yang holistik

Kolom-kolom dengan jumlah yang banyak dan tinggi, menunjukkan sesuatu yang berhubungan vertikal, simbol elemen ke-Illahi-an. Soko guru melambangkan empat hakikat kesempurnaan hidup. Dapat juga ditafsirkan sebagai hakikat dari sifat manusia. Kehadiran bentangan dan tiang penyangga dengan atap bersusun (biasanya dibiarkan menyerupai warna aslinya) menjadi ciri khas kehadiran pendopo dalam rumah dengan gaya ini, sekaligus menunjukkan status sosial pemiliknya. Tumpang dan sunduk (Ind: penusuk) merupakan penyambung atau penghubungan bagian soko guru. Posisi tumpang di atas sunduk. Lapisan balok kayu ini biasanya terdapat di bagian paling atas soko guru. Lapisan balok ini membentuk lingkaran-lingkaran bertingkat yang melebar ke arah luar dan dalam. Pelebaran ke bagian luar ini dinamakan elar (Ind: sayap). Sedangkan pelebaran ke bagian dalam disebut tumpang-sari. Elar menopang bidang atap, sementara tumpang-sari menopang bidang langit-langit joglo (pamidhangan).

Sisi holistik berikutnya adalah mengenai kenyamanan pandangan. Desain yang menusantara, dengan menggunakan warna-warna kayu pada interior dalamnya 
memberikan efek yang menenangkan. Kayu dan coklat menunjukkan kemaskulinan. Kemuliaan, namun tetap dalam kesehajaan. Kolom-kolom yang besar memberikan kesan kekuatan untuk menopang atap. Juga efek lain adalah rasa keamanan saat beribadah. Keholistikan ini mengkaitkan antara efek spiritual dan konstuksi ragawi.

Aktifitas seperti mengaji, sholat dan berdoa, secara tidak disadari menghasilkan aura dan membentuk kosmos disekitar mesjid menjadi nyaman dan sejuk. Ini terbukti dengan banyaknya pendapat orang yang ditanya mengenai kondisi udara, hampir semua merasa nyaman dan sejuk, padahal pada kondisi iklim yang sama namun dengan lokasi yang sedikit jauh saja dari mesjid ampel $( \pm 500 \mathrm{~m})$ udara sudah terasa sangat panas dan gerah. Hal ini terjadi dianalisa dua hal:

1. Doa, sholat dan ngaji memberikan ketenangan jiwa baik bagi pelaku ataupun pendengarnya. Jiwa yang tenang akan membuat orang merasa nyaman dengan kondisi apapun yang dirasakannya. Ketenangan ini memberikan suasana hening, suasana damai dan tentram bagi setiap jiwa yang ada di Mesjid Ampel. Meskipun suhu Surabaya cukup tinggi, namun tidak mempengaruhi kenyamanan yang dirasakan orang-orang di mesjid dan sekitarnya.

2. Lantunan suara Al Quran, baik dari orang yang sholat, maupun orang yang mengaji mampu merubah kosmos udara menjadi lebih segar. Merubah partikelpartikel udara menjadi kristal-kristal yang memberikan kesejukan dan kesegaran. Seperti penelitian yang dilakukan oleh orang Jepang mengenai perubahan kristal air ketika didengarkan kata-kata yang baik dan kata-kata yang kasar. Sama dengan udara, dimana di dalam udara juga terdapat partikel air. Partikel-partikel air di udara inilah yang berubah menjadi kristal-kristal yang mempengaruhi udara menjadi segar dan sejuk.

Bila ditinjau dari arsitektur biologis sebagai bagian dari holistiknya ekologis, kondisi udara yang segar, nyaman dan mengandung kristal-kristal air yang baik, tentu akan berefek pada kesegaran tubuh yang dirasakan oleh semua jiwa orang-orang yang ada di mesjid dan sekitarnya. Jiwa yang segar, akan berpengaruh pada kesehatan yang menjadi lebih baik. Sehingga tidak jarang hal ini yang membuat banyak orang yang ingin melakukan ziarah karena setelah ziarah mereka menjadi lebih baik.

Kondisi ini juga yang menyebabkan air di sekitar Mesjid Ampel dapat langsung diminum. Ini disebabkan lantunan ayat-ayat alquran mengubah kristal-kristal air menjadi kristal yang baik dan menyegarkan. Bahkan dapat berubah menjadi air yang memberikan kesembuhan. Itulah mengapa banyak peziarah yang membawa air ini pulang untuk dijadikan air penyembuh atau obat. Air yang ada diwadahi dari elemenelemen alam, meskipun telah diolah dari semen menjadi gentong, namun kemampuan gentong untuk bernafas karena memiliki pori-pori udara, membuat air yang ada di dalam gentong tetap segar dengan kandungan oksigen yang sangat banyak. Hal inilah yang mempengaruhi tingkat kemampuan air untuk menyegarkan dan menjadi penyembuh. Inilah yang dibahas dalam arsitektur holistik yaitu salah satunya memberikan desain yang dapat bermanfaat menjadi penyembuh.

Gentong-gentong air yang ada sangat banyak disebabkan banyaknya pengunjung. Seperti yang dibahas sebelumnya, jumlah air yang ada di lokasi ini tidak pernah habis, bahkan berlimpah ruah. Air adalah elemen yang hidup. Air senang ketika dapat bergerak. Ketika air bergerak, ia menghidupkan elemen hidup yang ada di dekat ataupun di dalamnya. Air yang diminum, kemudian dikembalikan ke alam adalah salah satu cara membuat air tersebut bergerak. Seperti air zamzam yang ada di Mekkah, tidak pernah habis diminum jutaan umat Islam seluruh dunia. Tidak hanya pada saat musim haji, tapi sepanjang hari sepanjang tahun dan setiap detik. Air tersebut 
berputar hingga seluruh pelosok dunia, menyebabkan air tersebut semakin banyak dan tidak berkurang.

\section{Hemat Energi.}

Berdasarkan pengamatan ke Mesjid Ampel, sistem pecahayaan mesjid pada pagi hingga sore hari sangat baik. Ini diperoleh dari pencahayaan yang masuk dari sekeliling fasade bangunan dan dari atap. Susunan atap memungkinkan cahaya masuk ke dalam mesjid ke tempat-tempat yang tidak memungkinkan cahaya dari samping berekspansi hingga ke daerah tersebut.

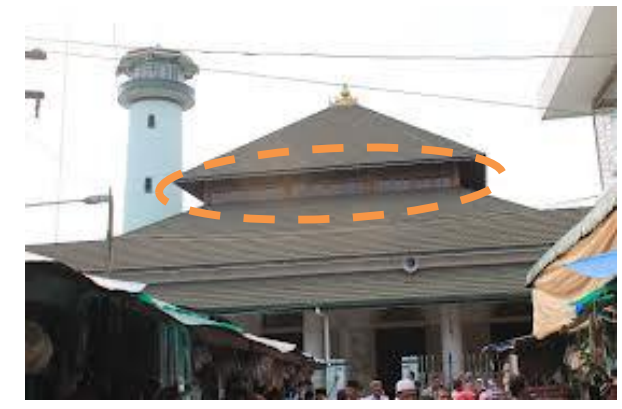

Gambar 5. Jendela yang memberikan penerangan dalam ruangan

Pada foto di atas, jendela diantara dua atap yang memungkinkan cahaya masuk ke dalam ruang untuk memberikan penerangan pada daerah tengah ruang. Ruang yang cukup terang memberikan bukti bawa lubang cahaya yang ada sudah cukup untuk menerangi ruang sehingga tidak dibutuhkan lagi penerangan buatan pada pagi hingga sore hari. Untuk bukaan pada dinding, tinggi jendela yang cukup sesuai memberikan kemampuan cahaya berekspansi cukup jauh ke dalam ruang. Ini terlihat dari garis terang cahaya pada foto berikut:

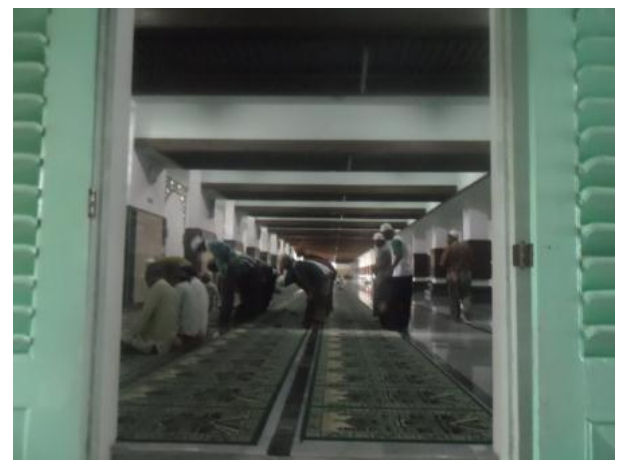

Gambar 6. Garis cahaya yang menerangi ruang yang bersumber dari jendela belakang dan depan

Jauhnya cahaya yang dapat masuk ke dalam ruang juga dipengaruhi oleh jarak antara bangunan. Cukupnya jarak antara mesjid dengan bangunan sekitarnya memungkinkan cahaya matahari masuk ke jendela dan menerangi ruangan. Cahaya yang masuk itu capat berupa cahaya langsung ataupun pantulan.

Ditinjau dari sisi penghawaan, bentuk atap dengan jendela yang memasukkan cahaya ke dalam ruang memberikan perbedaan kerapatan udara pada masing masing daerah. Daerah yang berada di bawah atap yang terkena cahaya menjadi panas. Panas yang ada meningkatkan tekanan udara dan menurunkan kerapatannya. Sedangkan daerah yang tidak terkena cahaya, tekanan udaranya rendah namun kerapatan udaranya tinggi. Perbedaan kerapatan ini kemudian membuat terjadi aliran udara dari daerah yang tidak terkena cahaya ke daerah yang terkena cahaya.

Konsep bukaan yang ada pada Mesjid Ampel sangat bagus karena memadukan jalusi dalam jendela dan pintu yang ada. Lubang ventilasi atas pintu juga didesain 
terbuka, sehingga udara dapat mengalir kapanpun dengan baik. Udara panas yang ada di atas dapat cepat terhapus dengan adanya ventilasi atap yang selalu terbuka. Pada saat mesjid tutup, udara tetap mengalir, sehingga tidak ada hawa panas yang tertahan di dalam ruang yang membutuhkan pendinginan lagi. Udara yang baik cukup menghemat energi listrik, karena tidak perlu didinginkan lagi.

Bentuk hemat energi lainnya diperoleh dari adanya teras. Teras berperan sebagai ruang peralihan dan penyimpan panas, barier panas agar tidak masuk ke dalam bangunan utama. Teras ini memiliki lebar yang cukup baik untuk mengurangi panas dari luar sebelum masuk ke dalam gedung.

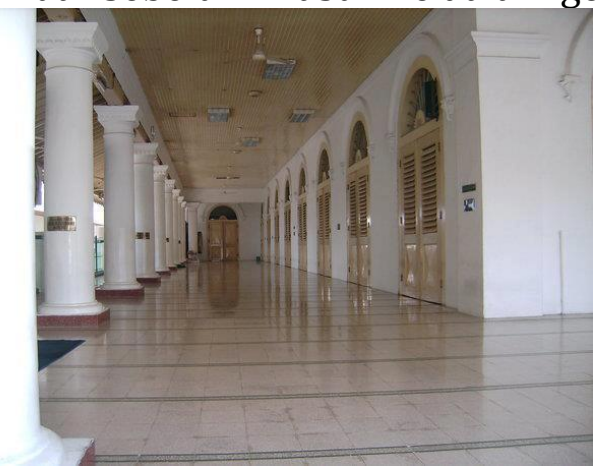

Gambar 7. teras sebagai ruang peralih yang mengurangi panas

Teras, juga berperan memberikan volume ruang yang tidak terkena matahari yang lebih besar. Daerah yang lebih besar ini baik untuk memberikan beda tekanan pada mesjid yang dapat berpengaruh pada terbentuknya aliran angin. Adanya aliran angin dapat mengurangi beban panas yang dikeluarkan manusia dan bangunan, sehingga akibat berikutnya adalah penghematan energi.

\section{Material Ramah Lingkungan.}

Mesjid Ziarah Ampel hampir seluruhnya menggunakan bahan-bahan dari alam yang masih memiliki pori sehingga masih bisa tetap bernafas. Dimulai dari bahasan penutup lantai sekitar mesjid. Material yang digunakan adalah paving. Material paving ini memungkinkan penyerapan air karena memiliki rongga diantara paving. Walaupun presentasi air yang diresapkan sangat sedikit. Untuk usulan perbaikan adalah menggunakan paving yang berlubang di tengahnya. Hanya saja bila menggunakan paving jenis tersebut, perlu perawatan ekstra karena daerah ini adalah daerah yang sangat banyak dilewati oleh orang. Sehingga tidak memungkinkan mengisi rumput di celah air yang ada. Yang mungkin adalah memasang kerikil di antara lubang paving yang ada.

Lantai lain yang digunakan di luar adalah lantai batu alam. Batu alam alam adalah elemen hidup yang bernafas. Memuai dan menyusut sesuai dengan perubahan iklim yang terjadi. Batu ini sangat ramah lingkungan, sehingga sangat baik untuk dipergunakan baik di dalam maupun di luar bangunan.Lantai-lantai dengan batu alam dipasang di daerah-daerah pintun gerbang. Kelebihannya adalah permukaan yang kasar yang mengurangi kemungkinan orang untuk terpeleset.

Lantai yang digunakan dalam masjid adalah granit dan marmer. Lantai granit dan marmer adalah batuan murni yang yang berpori sehingga memungkinkan daerah yang tertutupi tetap bernafas walaupun sangat sedikit. Dibandingkan porselen, kedua material ini memberikan efek yang dingin di kaki. Efek dingin ini cukup baik untuk menambah kesejukan ruang karena Surabaya berada pada daerah yang cukup panas. Lantai porselen yang dipasang di luar memiliki tekstur nyang cukup baik untuk 
kondisi udara luar. Ketika terkena percikan atau bekas wudhu, permukaan tetap kasar sehingga mengurangi kemungkinan terpeleset.

Dinding terbuat dari bahan tembok dengan ketebalan satu bata. Ketebalan ini cukup baik untuk menahan panas dari luar masuk ke dalam. Ketebalan ini memiliki timelag yang cukup lama sehingga panas yang diserap dinding luar dari sinar matahari, masih belum sampai ke dalam sudah berganti hari lagi.sehingga kemungkinan panas masuk ke bangunan cukup lama. Dinding dari paduan semen, pasir dan bata, merupakan bahan-bahan yang dapat hancur sehingga tidak merusak alam. Daya tahan material ini pun cukup lama, masih dapat bertahan sampai sekarang meskipun telah dibangun dalam waktu ratusan tahun.

Kusen, pintu, dan tiang menggunakan bahan kayu dengan kualitas dan kekuatan kayu nomer 1. Kayu jati terkenal dengan kekuatan dan daya tahannya. Material ini sangat baik, selain itu memiliki tekstur dan motif yang baik. Hanya saja sayangnya, pintu dan jendela akhirnya ditutup dengan menggunakan bahan cat.

Soko guru menggunakan bahan kayu jati yang diekspos. Penggunaan jati ini menguatkan perasaan orang yang ada di dalamnya. Jati juga adalah elemen hidup yang akan memuai menyusut sesuai dengan perubahan lingkungan. Namun karena waktu yang sudah cukup panjang, jati ini sudah mengalai perubahan yang tidak sigifikan. Sehingga ikatan antara konsruksi sudah menjadi lebih kuat.

Konstruksi yang digunakan pada bagian atap menyerupai konstruksi rangka, dengan penutup atap dari genteng. Terdapat kuda-kuda, gording, kaso dan reng. Yang diekspos pada sisi luar adalah kasonya. Bahan penutup atap yang digunakan adalah kayu jati. Dulu Sunan Ampel memilih bahan yang benar-benar berkualitas untuk membangun mesjidnya.

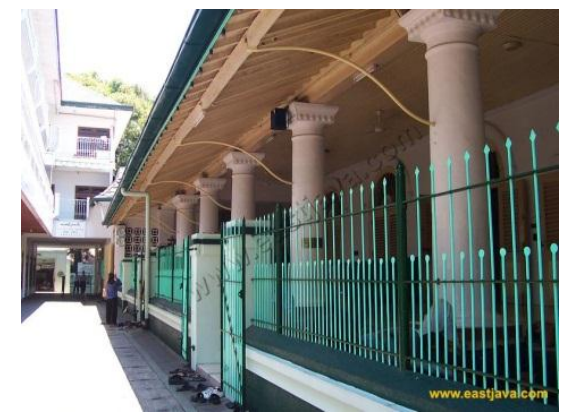

Gambar 8. Materil Plafon yang di Ekspos

Pada foto yang ada terlihat material yang diekspos dengan baik dan difinish dengan menggunakan finish clear. Finish ini menguatkan kualitas jati. Mengangkat serat jati untuk terlihat lebih baik yang kemudian menunjukkan tampilan mesjid yang lebih baik. Tidak ditutupinya bahan ini membuat kayu menjadi lebih mudah untuk bernafas dengan baik, sehingga tetap berkesinambungan dengan perubahan alam.

Baiknya kualitas bahan-bahan yang ada juga dipengaruhi oleh fungsi bangunan sebagai masjid. Lantunan ayat-ayat Al Quran membuat material yang ada tetap dalam keadaan baik, dan memberi dampak yang baik pula ke lingkungan sekitarnya. Manusia memiliki hubungan yang kuat dengan lingkungannya. Bagaimana kondisi suatu lingkungan sangat ditentukan oleh manusia yang memiliki kewenangan atas lingkungan tersebut. Demikian pula sebaliknya, lingkungan dapat mempengaruhi manusia. Rapoport, dalam On 'The Visible in Architecture': An EBS-Perspective, membawa arsitektur (dan desain) dalam konteks yang lebih luas serta melibatkan lebih banyak aspek. Pertama, arsitektur bukanlah bangunan tunggal, tetapi bangunan dan lingkungannya. Arsitektur melibatkan lingkungan terbangun (lebih tepat: lingkungan binaan) yang oleh ahli geografi disebut cultural landscape (saujana 
budaya). Pemahaman saujana budaya memandang arsitektur dalam konteks yang lebih luas, tak hanya bangunan (sebagaimana teori-teori dalam literatur-literatur yang digunakan sebagai referensi desain arsitektur) tetapi lingkungan di mana manusia mempengaruhi bentukan lingkungan tersebut. Kedua, arsitektur dibentuk oleh sistemsistem yang tak kasat mata (invisible) yang diekspresikan dalam system of settings yang kasat mata (visible).

Bahan penutup atap terbuat dari genteng. Genteng adalah material yang dibuat dari alam, baik itu genteng tanah maupun genteng beton. Sehingga karena terbuat dari bahan alam, material ini juga cukup baik dan ekologis.

\section{Peka Terhadap Iklim}

Meninjau dari sisi lintasan, bangunan tidak tegak lurus terhadap lintasan matahari tetapi membentuk sudut. Sudut ini memungkinkan berkurangnya panas ke bangunan. Selain itu ada jarak yang cukup antara mesjid dengan bangunan sekitarnya memungkinkan angin untuk berhembus masuk ke dalam mesjid

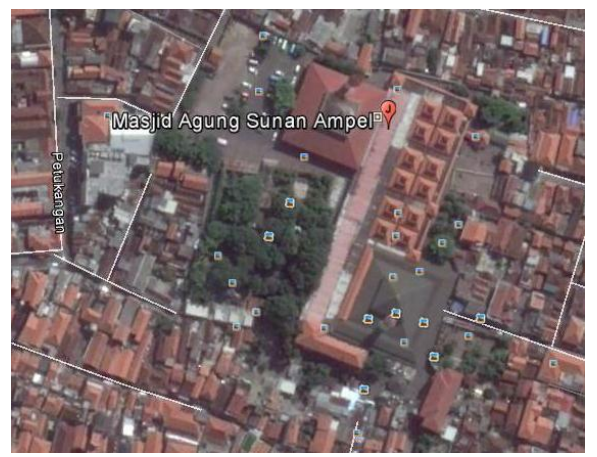

Gambar 9. lokasi mesjid terhadap bangunan sekitar

Selain jarak antara bangunan sekitar dengan mesjid, mesjid juga memiliki teras yang memungkinkan adanya daerah kosong untuk pergerakan udara. Desain jendela cross ventilasi memperlancar pergantian udara dalam ruang. Jendela pada atap memungkinkan cahaya dan udara mengalir lancer sehingga pergantian udara yang cukup baik.

\section{Kesimpulan}

Berdasarkan hasil kajian ke mesjid ziarah Ampel, beberapa hal yang baik diusulkan sebagai berikut:

1. Membuat kumpulan pepohonan di sekitar mesjid untuk memberikan efek pergerakan angin, penyaring debu dan suara berlebih, pemasok oksigen.

2. Memberi jarak yang cukup antara bangunan mesjid dengan sekitar sehingga ada daerah untuk cahaya matahari masuk dan juga udara.

3. Membuat teras sebagai ruang peralihan udara dan pengguna.

4. Doa, sholat dan ngaji memberikan ketenangan jiwa bagi pelaku dan pendengarnya. Jiwa yang tenang membuat orang merasa nyaman dengan kondisi apapun yang dirasakannya. Ketenangan ini memberikan suasana hening, suasana damai dan tentram bagi setiap jiwa yang ada di mesjid ziarah ampel. Sehingga meskipun temperatur Surabaya yang cukup tinggi, tidak mempengaruhi kenyamanan yang dirasakan orang-orang yang ada di mesjid dan sekitar mesjid.

5. Lantunan suara alquran mampu merubah kosmos udara menjadi lebih segar. Merubah partikel-partikel udara menjadi kristal-kristal yang memberikan kesejukan dan kesegaran. Seperti penelitian yang dilakukan oleh orang Jepang 
mengenai perubahan kristal air ketika didengarkan kata-kata yang baik dan katakata yang kasar. Sama dengan udara, dimana di dalam udara juga terdapat partikel air. Partikel-partikel air di udara inilah yang berubah menjadi kristal-kristal yang mempengaruhi udara menjadi segar dan sejuk.

6. Penggunaan bahan yang tidak merusak lingkungan.

Manusia memiliki hubungan yang kuat dengan lingkungannya. Kondisi lingkungan ditentukan oleh manusia yang memiliki kewenangan atas lingkungan tersebut. Demikian pula sebaliknya, lingkungan dapat mempengaruhi manusia, membawa arsitektur (dan desain) serta melibatkan lebih banyak aspek. Arsitektur bukanlah bangunan tunggal, tetapi bangunan dan lingkungannya. Arsitektur melibatkan lingkungan terbangun (lebih tepat: lingkungan binaan) yang oleh ahli geografi disebut cultural landscape (saujana budaya). Arsitektur bukan hanya bangunan, tetapi lingkungan di mana manusia mempengaruhi bentukan lingkungan tersebut. Kedua, arsitektur dibentuk oleh sistem-sistem yang tak kasat mata (invisible) yang diekspresikan dalam system of settings yang kasat mata (visible).

\section{DAFTAR PUSTAKA}

Attoe, Wayne. 1978. Architecture and Critical Imagination. Old Woking-England: John Willey \& Sons, Ltd.

Budihardjo, Eko. 2004. S.O.S Warisan Arsitektur Indonesia. Arsitektur dan Kota di Indonesia $5^{\text {th. }}$ Bandung: P.T Alumni.

Hatmoko, Adi Utomo. 1999. Weaving Heritage Sites into Larger Context. Procedding of International Seminar on Vernacular Settlement, Faculty of Engineering University of Indonesia. Jakarta

Hidayat, Anas. 2010. Arsitektur Koprol: Menyentik Surabaya, Menggelitik Jawa Timur. Surabaya: Dewan Kesenian Jawa Timur

Khan, Hasan ud-Din. 1994. An Overview of Contemporary Mosques, Martin Frishman

\& Hasan ud-Din Khan (eds.), Mosque: History, Architectural Development and Regional Diversity. London: Thames \& Hudson.

Kropotkin, Peter. 2006. Gotong Royong Kunci Kesejahteraan Sosial, Tumbangnya Darwinisme Sosial. Kota Depok: Piramedia

Mangunwijaya, Y.B. 1992. Sastra dan Religiositas. Yogyakarta: Kanisius.

Moenadi MS, Ki. 2000. Satu Kesatuan Ketepatan-Keterpaduan Rajutan (Sistem) Dzat Ketenagaan Hidup yang Indah-Lurus-Teratur. Malang: Yayasan Badiyo.

Pangarsa, Galih Widjil. 2011. DNA Arsitektur Nias pada Lorong Gravitasi Nusantara Kontemporer, (E-book Engine on arsiteknusantara.blogspot.com), Malang: @You Publish. [10 Agustus 2011]

Pangarsa, Galih W. 2010. Materialisme pada Masjid Nusantara. (E-book Engine on arsiteknusantara.blogspot.com), Malang: @You Publish. [10 Agustus 2011]

Pangarsa, Galih W. 2008. Arsitektur untuk Kemanusiaan. Surabaya: Wastu Lanas Grafika

Prawoto, Eko Agus. 2009. Arsitektur Untuk Kemanusiaan, Peziarahan Panjang Humanisme Mangunwijaya. Jakarta: Penerbit Buku Kompas.

Santosa, Revianto B, 1999. Atap (Masjid Sunan Ampel) Dalam Dinamika Arsitektur Masjid Kontemporer Nusantara, SNEIDAN 2: Atap Arsitektur Masjid. Surabaya: LSAI Santosa, Revianto Budi. 2000. Omah: Membaca Makna Rumah Jawa. Yogyakarta: Yayasan Bentang Budaya.

Zen, Kang. (2010). Spiritual Sinergi Semesta. Bogor: ABCo Publisher. 